\title{
Efektivitas Program Desa Migran Produktif (DESMIGRATIF) Pada Dinas Tenaga Kerja dan Transmigrasi Kabupaten Subang
}

\author{
Komir Bastaman ${ }^{1}$ \\ Fakultas Ilmu Administrasi Universitas Subang \\ komirbastaman60@gmail.com
}

\section{Ade Nawawi2}

Fakultas Ilmu Administrasi Universitas Subang

adenawawi15.an@gmail.com

\author{
Taharudin $^{3}$ \\ Universitas Lambung Mangkurat \\ taharuddintd@gmail.com
}

\begin{abstract}
Abstrak
Tujuan penulis melakukan penelitian ini untuk mengetahui Efektivitas Program Desa Migran Produktif pada Dinas Tenaga Kerja dan Transmigrasi Kabupaten Subang. Penelitian dan penulisan ini membahas hal-hal yang berkaitan dengan bagaimana Efektivitas Program Desa Migran Produtif pada Dinas Tenaga Kerja dan Transmigrasi Kabupaten Subang sesuai dengan teori yang dikemukakan oleh Answar Annas yang meliputi Ketepatan waktu, Sumber daya manusia, Mekanisme Kerja, Kerjasama dan Komunikasi, Penyaluran dana yang benar, Tidak ada penyimpangan, Monitoring dan evaluasi. Dalam penelitian ini menggunakan pendekatan kualitatif yang bersifat deskriptif, karena penelitian ini bertujuan untuk mengembangkan pengertian, konsep-konsep yang pada akhirnya memperoleh gambaran yang kemudian diteliti digunakan untuk mengungkapkan permasalahan dalam kehidupan kerja organisasi pemerintah melalui observasi, wawacara, studi kepustakaan dan dokumentasi. Sumber data yang diperoleh dari informan melalui pengamatan dan wawancara langsung dan dokumen diperoleh dalam bentuk foto atau rekaman, perataturanperaturan dan pengolahan data. Hasil penelitian menunjukan bahwa Efektivitas Program Desa Migran Produktif pada Dinas Tenaga Kerja dan Transmigrasi Kabupaten Subang sesuai dengan teori pengukuran efektivitas program yang dikemukakan oleh Answar Annas belum optimal. Kesimpulan temuan dilapangan yaitu Ketepatan waktu, Sumber daya manusia, Mekanisme kerja, Kerjasama dan Komunikasi, Penyaluran dana yang benar, Tidak ada penyimpangan, Monitoring dan evaluasi dinilai belum sesuai dengan teori yang digunakan.
\end{abstract}

Kata kunci: Efektivitas Program, Desa Migran Produktif 


\section{Abstract}

The purpose of the authors conducted this study was to determine the Effectiveness of the Productive Migrant Village Program at the Subang District Manpower and Transmigration Office. This research and writing discusses matters relating to how the Effectiveness of Produtive Village Migrant Program in the Subang Regency Manpower and Transmigration Office in accordance with the theory put forward by Answar Annas which includes Timeliness, Human Resources, Work Mechanisms, Collaboration and Communication, Distribution correct funds, There are no deviations, Monitoring and evaluation. In this study using a qualitative approach that is descriptive, because this study aims to develop understanding, the concepts that ultimately obtain a picture which is then examined are used to reveal problems in the work life of government organizations through observation, interviews, literature studies and documentation. Sources of data obtained from informants through direct observation and interviews and documents obtained in the form of photos or records, regulations and data processing. The results showed that the Effectiveness of the Productive Migrant Village Program at the Subang Regency Manpower and Transmigration Office in accordance with the theory of program effectiveness measurement proposed by Answar Annas was not optimal. Conclusions from the field findings are timeliness, human resources, work mechanism, cooperation and communication, correct distribution of funds, no deviations, monitoring and evaluation are considered not in accordance with the theory used.

Keywords: Program Effectiveness, Productive Migrant Village

\section{Pendahuluan}

Indonesia sebagai negara berkembang selalu menghadapi berbagai masalah seperti Tingginya tingkat pengangguran, kemiskinan, rendahnya tingkat pendidikan, adanya kesenjangan sosial, dan sebagainya. Kehidupan yang layak saat ini sangatlah sulit karena adanya persaingan yang ketat, penggunaan teknologi yang semakin canggih, dan kondisi politik yang tidak stabil menjadi tantangan bagi pemerintah.

Pembangunan Nasional bertujuan untuk mewujudkan masyarakat Indonesia yang adil dan makmur, merata, materil, spiritual, melalui peningkatan taraf hidup masyarakat, kecerdasan dan kesejahteraan rakyat. Pembangunan tersebut diharapkan dapat dilaksanakan secara merata bagi seluruh rakyat. Pembangunan akan berjalan secara optimal apabila ditunjang oleh sumber daya manusia yang baik, dengan memiliki Indikator Pembangunan Manusia atau Human Development Index (HDI) yang tinggi. Ditambah dengan pembangunan ketenagakerjaan yang ditunjukan dengan perluasan lapangan kerja, pemerataan kesempatan kerja, peningkatan mutu serta perlindungan tenaga kerja. Mensejahterakan masyarakat dalam segala bidang adalah salah satu cita-cita pemerintah. Tetapi banyak kendala untuk mewujudkannya sehingga harapan pemerintah untuk menciptakan kemandirian masyarakat sulit tercapai. Kemandirian masyarakat adalah wujud dari pengembangan kemampuan ekonomi daerah untuk menciptakan kesejahteraan dan memperbaiki material secara adil dan merata yang ujungnya berpangkal pada pemberdayaan masyarakat. 
Efektivitas adalah seberapa baik pekerjaan dilakukan dan sejauh mana seseorang menghasilkan keluaran yang sesuai dengan yang diharapkan. Ini dapat diartikan bahwa apabila sesuatu pekerjaan dapat dilakukan sesuai dengan yang direncanakan, maka dapat dikatakan efektif. Penilaian efektivitas program perlu dilakukan untuk menemukan informasi tentang sejauh mana manfaat dan dampak yang ditimbulkan oleh program kepada penerima program. Hal ini juga menentukan dapat tidaknya suatu program dilanjutkan. efektivitas tidak hanya berbicara tentang pencapaian tujuan namun bagaimana organisasi dapat mempertahankan diri dari berbagai ancaman dari luar dan dari dalam sehingga organisasi dapat berkelanjutan dalam menjalankan tugas, pokok dan fungsi.

Pekerja Migran Indonesia (PMI) adalah setiap warga negara Indonesia yang akan, sedang, atau telah melakukan pekerjaan dengan menerima upah di luar wilayah Republik Indonesia. Dengan keterbatasan kesempatan kerja di dalam negeri dan disparitas upah yang jauh berbeda dengan diluar negeri, ini menjadi faktor pendorong utama Calon Pekerja Migran Indonesia (CPMI) untuk bekerja di luar negeri.

Sesuai Undang-undang nomor 18 Tahun 2017 Tentang Perlindungan Pekerja Migran Indonesia (PMI) menyatakan setiap Warga Negara Indonesia (WNI) yang memenuhi syarat untuk bekerja di luar negeri dalam hubungan kerja untuk jangka waktu tertentu dengan menerima upah. Calon Pekerja Migran Indonesia (CPMI) adalah setiap warga negara Indonesia yang memenuhi syarat sebagai pencari kerja yang akan bekerja di luar negeri dan terdaftar di instansi pemerintah kabupaten/kota yang bertanggung jawab di bidang ketenagakerjaan. Berdasarkan jenis pekerjaannya, Pekerja Migran terbagi menjadi dua yaitu Pekerja Migran Indonesia formal dan Pekerja Migran Indonesia informal. Pekerja Migran Indonesia formal adalah Pekerja Migran yang bekerja di perusahaan negara atau swasta di luar negeri yang berbadan hukum. Pekerja Migran Indonesia formal saat ini tersebar di beberapa sektor seperti sektor industri, sektor perikanan, sektor perkebunan, dan sektor kesehatan. Sedangkan, Pekerja Migran Indonesia informal adalah Pekerja Migran yang bekerja dengan perorangan dan/atau bukan perusahaan negara atau swasta di luar negeri. Pada umumnya, Pekerja Migran informal bekerja sebagai Pekerja Rumah Tangga.

Mayoritas tenaga kerja yang berasal dari Indonesia, berketerampilan rendah dan bekerja di sektor informal. Pekerja Migran, terutama yang bekerja di sektor informal, seringkali tidak mengetahui atau tidak diberitahu mengenai realitas migrasi, hak yang seharusnya mereka peroleh termasuk prosedur bermigrasi yang legal dan aman, serta bagaimana mengakses layanan bantuan ketika mengalami masalah. Hal ini membuat para Pekerja Migran menjadi sangat rentan terhadap perekrutan yang menyeleweng, mengalami tindak kekerasan baik fisik maupun psikologis, eksploitasi, bahkan perdagangan orang sepanjang proses migrasi, yang pada akhirnya membuat mereka masuk kedalam daftar Pekerja Migran Indonesia Bermasalah (PMIB). Pekerja Migran Indonesia Bermasalah (PMIB) adalah setiap Pekerja Migran yang sedang menghadapi masalah, baik permasalahan ketenagakerjaan maupun non ketenagakerjaan. Pekerja Migran Indonesia Bermasalah tidak hanya berasal dari sektor informal, melainkan dapat pula berasal dari sektor formal. Namun, selama ini sebagian besar Pekerja Migran yang mengalami masalah ialah Pekerja Migran yang berangkat secara non prosedural (atau juga dikenal dengan istilah Pekerja Migran 
Indonesia ilegal) yang umumnya merupakan Pekerja Migran yang bekerja di sektor informal.

Desa Migran adalah desa dengan sebagian besar anggota masyarakat bekerja sebagai Pekerja Migran Indonesia, Desa Migran Produktif yang selanjutnya disebut Desmigratif adalah Desa Migran yang telah ditetapkan sebagai penerima program pemberdayaan Komunitas Pekerja Migran Indonesia. Penyelenggaraan pemberdayaan Komunitas Pekerja Migran Indonesia di Desa Migran Produktif dilaksanakan secara terintegrasi dan berkesinambungan. sesuai Peraturan Menteri Ketenagakerjaan No.2 Tahun 2019 tentang Komunitas Pekerja Migran di Desa Migran Produktif Pembentukan Desa Migran Produktif

Program Desa Migran Produktif (Desmigratif) adalah upaya terobosan kementrian ketenagakerjaan bekerjasama dengan berbagai lembaga untuk memberdayakan, meningkatkan pelayanan serta memberi pelindungan bagi Calon Pekerja Migran Indonesia/Pekerja Migran Indonesia di desa yang menjadi kantong-kantong Pekerja Migran, dengan menawarkan program-program unggulan yang dibutuhkan oleh Calon Pekerja Migran Indonesia/Pekerja Migran Indonesia dan keluarganya melalui pemanfaatan potensi lokal dengan tidak mengabaikan karakteristik daerah setempat. Kabupaten Subang merupakan kabupaten pengirim tenaga kerja terbesar ke tiga seProvinsi Jawa Barat, Seiring dengan banyaknya penggangguran yang berada di kabupaten subang ditambah dengan sempitnya lapangan kerja, membuat banyak masyarakat yang berpikiran untuk bekerja diluar negeri. Menjadikan pilihan untuk bekerja ke luar negeri masih menjadi daya tarik bagi sebagian besar masyarakat. Menurut data Badan Pusat Statistik Tahun 2018, Kabupaten Subang memiliki jumlah penduduk sebanyak 1.562.509 Jiwa dengan jumlah pengangguran sebanyak 69.358 jiwa. Data dari Dinas Tenaga Kerja dan Transmigrasi pada tahun 2018 ada sebanyak 6.807 Pekerja Migran Indonesia (PMI) yang berasal dari kabupaten Subang.

Desa Pusakaratu adalah salah satu desa di Kecamatan Pusakanagara, luas wilayah 4,81 Km², terdiri dari $22 \mathrm{RT}, 4 \mathrm{RW}, 6$ Dusun dengan jumlah penduduk sebanyak 9.884 Jiwa dan Jumlah Kepala Keluarga sebanyak 2.572 KK. Desa Pusakaratu memiliki penduduk yang terbanyak se-kecamatan Pusakanagara, dan di Desa Pusakaratu juga adalah desa yang terbanyak mengirimkan Pekerja Migran setiap tahunnya. Selain itu ada sebanyak 301 anak-anak yang orangtuanya menjadi Pekerja Migran, mereka diasuh oleh Ayah, nenek dan kakeknya bahkan oleh saudaranya. Mereka kurang perhatian dan bimbingan sehingga banyak yang terjerumus pada pergaulan bebas sehingga banyak yang Narkoba, Hamil diluar nikah, LGBT, HIV dan lain sebagainya. Dalam hal Pendidikan, mereka pun banyak yang tidak mempedulikan dikarenakan mereka selalu berfikir untuk apa berpendidikan tinggi karena nanti pun akan bekerja diluar negeri.

Selain itu para Pekerja Migran Indonesia belum mampu memanfaatkan hasil kerja yang mereka peroleh untuk usaha-usaha yang bersifat produktif, namun lebih cenderung berperilaku konsumtif, begitu pula dengan keluarganya sehingga mereka cenderung untuk memilih kembali bekerja ke luar negeri. Jika di presentasekan kurang lebih hanya 7,9\% yang dapat membangun usaha produktif di Desa Migran. Memang sangat sulit untuk merubah pola pikir dan kebiasaan masyarakat. Karena jika sudah terbiasa maka akan sulit untuk berubah. 
Berdasarkan hasil observasi yang telah dilakukan, penulis menemukan permasalahan di lapangan yaitu Pekerja Migran Indonesia yang belum bisa mengembangkan potensi dalam dirinya secara optimal, sehingga Program Desa Migran Produktif Dinas Tenaga Kerja dan Transmigrasi di Kabupaten Subang belum berjalan dengan optimal, hal ini dapat dilihat dari indikator sebagai berikut:

1. Masyarakat banyak yang belum mengetahui tentang Program Desa Migran Desa Produktif karena dari jumlah migran sebanyak 394 baru dibina sebanyak 40 migran.

2. Purna Pekerja Migran belum mampu memanfaatkan hasil kerja yang mereka peroleh untuk usaha-usaha yang bersifat produktif, dari 394 jumlah migran di Desa Pusakaratu, hanya terdapat 40 orang yang memiliki usaha produktif, sehingga jika dipersentasekan hanya sekitar $7.9 \%$ yang telah membangun usaha produktif.

3. Kurangnya monitoring dan pembinaan dari Dinas terkait untuk tumbuh kembang anak migran karena ada 301 anak-anak yang orangtuanya menjadi Pekerja Migran di Desa Pusakaratu yang belum terbina.

\section{Kerangka Teori}

\section{Konsep Efektivitas}

Dari segi etimologi kata efektif yang kita pakai di Indonesia merupakan padanan kata dari bahasa Inggris yaitu dari kata "effective". Arti dari kata ini yakni berhasil atau sesuatu yang dilakukan berhasil dengan baik. Sedangkan dalam Kamus Besar Bahasa Indonesia, kata efektivitas mempunyai beberapa pengertian yaitu, akibatnya, pengaruh dan kesan, manjur, dapat membawa hasil. Dalam kamus-kamus Ilmiah Populer, efektivitas adalah ketepat gunaan, hasil guna, menunjang tujuan.

Suatu organisasi dikatakan efektif bila organisasi itu mencapai tujuan dalam organisasi tersebut. Dalam hal ini, efektivitas sebagai tingkat pencapaian organisasi dalam jangka pendek dan jangka panjang. Organisasi itu efektif bila memenuhi kepuasan pelanggan, mencapai visi organisasi, pemenuhan aspirasi, menghasilkan keuntungan bagi organisasi, pengembangan sumber daya manusia organisasi, dan aspirasi yang dimiliki, serta memberikan dampak positif bagi masyarakat di luar organisasi. Menurut Steers (dalam buku Edy Sutrisno: 123) menyatakan bahwa yang terbaik dalam efektivitas iyalah memperhatikan secara serempak tiga buah konsep yang saling berkaitan (1) Optimalkan tujuan-tujuan: (2) Prespektif system, dan (3) Tekanan pada segi perilaku manusia dalam susunan organisasi. Efektivitas pada dasarnya mengacu pada sebuah keberhasilan atau pencapaian tujuan. Efektivitas merupakan salah satu dimensi dari produktivitas (hasil) yaitu mengarah pada pencapaian unjuk kerja yang maksimal, yaitu pencapaian target yang berkaitan dengan kualitas, kuantitas dan waktu. Efektivitas adalah suatu ukuran yang menyatakan seberapa jauh target (kuantitas, kualitas dan waktu) telah dicapai. Dimana makin besar presentase target yang dicapai, makin tinggi efektivitasnya.

Steers (1985:87) efektivitas adalah jangakuan usaha suatu program sebagai suatu system dengan sumber daya dan sarana tertentu untuk memenuhi tujuan dan sarananya tanpa melumpuhkan cara dan sumber daya itu serta tanpa member 
tekanan yang tidak wajar terhadap pelaksanaannya. Efektivitas adalah suatu kondisi atau keadaan, dimana dalam memilih tujuan yang hendak dicapai dan sarana yang digunakan, serta kemampuan yang dimiliki adalah tepat, sehingga tujuan yang diingkan dapat dicapai dengan hasil yang memuaskan". Jadi efektivitas organisasi adalah tingkat keberhasilan organisasi dalam usaha untuk mencapai tujuan atau sasaran. Dengan demikian, pengertian efektivitas dalam beberapa definisi di atas menunjukan pada kualifikasi sampai seberapa jauh tercapainya suatu tujuan yang terlebih dahulu ditentukan. Dapat dikatakan bahwa efektivitas merupakan suatu konsep yang menggambarkan tentang keberhasilan suatu organisasi dalam mencapai tujuannya. Jadi efektivitas adalah pengukuran keberhasilan dalam pencapaian tujuan yang telah ditetapkan dengan pemakaian proses yaitu pemilihan cara-cara yang sesuai dengan tujuan. Keefektifan adalah derajat dimana organisasi mencapai tujuannya. Sedangkan efektivitas adalah kesesuaian hasil yang dicapai organisasi dengan tujuan atau sasaran yang telah ditetapkan. Pemaparan di atas menunjukan bahwa tujuan menjadi pokok pertama dan utama dari sebuah kegiatan dalam suatu organisasi. Dengan kata lain unsure yang penting dalam teori efektivitas adalah pencapaian tujuan yang sesuai dengan apa yang telah disepakati secara maksimal. Tujuan itu tidak lain adalah harapan yang dicita-citakan atau suatu kondisi tertentu yang ingin dicapai oleh serangkaian proses. Adapun perumusan tujuan dan proses mencapai tujuan itu melibatkan berbagai komponen, antara lain tenaga, sarana dan prasarana, serta waktu. Efektivitas juga disebut hasil guna. Efektivitas selalu terkait dengan hubungan antara hasil yang diharapkan dengan hasil yang sesungguhnya dicapai. Seperti yang dikemukakan oleh (Gedeian dkk, 1991: 61) bahwa efektivitas adalah "that is, the greater the extent in which organization's goals are met or surpassed, the greater its effectiveness" (semakin besar pencapian tujuan-tujuan organisasi semakin besar efektivitasnya). Efektivitas yaitu suatu keadaan tercapainya tujuan yang diharapkan atau dikehendaki melalui penyelesaian pekerjaan sesuai rencana yang telah ditentukan.

Pengertian efektivitas menurut beberapa ahli lainnya seperti (Siagian, 2001:24) efektivitas adalah pemanfaatan sumberdaya sarana dan prasarana dalam jumlah tertentu dalam jumlah sadar ditetapkan sebelumnya untuk menghasilkan sejumlah barang dan jasa kegiatan yang dijalankanya. Efektivitas menunjuk keberhasilan dari segi tercapai tidaknya sarana yang telah ditetapkan. Jika hasil kegiatan semakin mendekati sarana kegiatan, berarti makin tinggi efektivitasnya. Pandangan lain dikemukakan oleh (Sunghanda, 2003:147) bahwa efektivitas adalah pemanfaatan sumber daya, sarana dan prasarana dalam jumlah tertetu yang sacara sadar ditetapkan sebelumnya untuk menghasilkan sejumlah pekerjaan tepat pada waktunya. Berdasarkan pendapat-pendapat para ahli tersebut dapat disimpulkan bahwa, efektivitas adalah tingkat pencapaian tujuan atau sasaran organisasional sesuai dengan yang telah ditetapkan. Efektivitas adalah seberapa baik pekerjaan dilakukan. Sejauh mana seseorang menghasilan keluaran yang sesuai dengan yang diharapkan. Ini dapat diartikan bahwa apabila sesuatu pekerjaan dapat dilakukan dengan baik sesuai dengan yang direncanakan, maka dapat dikatakan efektif dengan mengukur efektivitas suatu program.

\section{Efektivitas Program}


Efektivitas berasal dari efektif yang mengandung pengertian dicapainya keberhasilan dan mencapai tujuan yang telah ditetapkan. Efektivitas selalu terkait dengan hubungan antara hasil yang diharapkan dengan hasil yang sesungguhnya dicapai. Kamus ilmiah popular mendefinisikan efektivitas sebagai ketepatan penggunaan, hasil guna atau penunjang tujuan. Gie (2004:34) memberikan definisi efektivitas sebagai keadaan yang mengandung pengertian mengenai terjadinya suatu efek atau akibat yang dikehendaki, maka perbuatan itu dikatakan efektif kalau menimbulkan akibat atau mencapai maksud sebagaimana yang dikehendaki. Penulis menganalisis pengertian diatas bahwa efektif atau tidaknya suatu pekerjaan atau usaha suatu organisasi dapat dilihat dari sasaran dan tujuan yang dicapai.

Pengertian lain menurut Mahmudi (2005:92) mendefinisikan efektivitas sebagai berikut : "efektivitas merupakan hubungan antara output dengan tujuan, semakin besar kontribusi (sumbangan) output terhadap pencapaian tujuan, maka semakin efektif organisasi, program atau kegiatan". Berdasarkan pendapat tersebut, bahwa efektivitas mempunyai hubungan timbal balik antara output dengan tujuan semakin besar kontribusi output, maka akan semakin efektif suatu program atau kegiatan. Sehubungan dengan hal tersebut di atas, maka efektivitas adalah menggambarkan seluruh siklus input (masukan), proses atau output (hasil) yang mengacu pada hasil guna daripada suatu organisasi, program atau kegiatan yang menyatakan sejauh mana tujuan (kualitas, kuantitas, dan waktu) telah dicapai serta ukuran berhasil tidaknya suatu organisasi mencapai tujuannya dan mencapai target-targetnya. Hal ini berarti, bahwa pengertian efektivitas yang dipentingkan adalah semata-mata hasil atau tujuan yang di kehendaki. Pandangan yang sama menurut pendapat Peter F. Drucker yang dikutip Yayat M. Herujito (2001:9) yang mendefinisikan efektivitas, sebagai berikut "efektivitas berarti menjalankan pekerjaan yang benar, pada sisi lain efektivitas adalah kemampuan untuk memiliki sasaran yang tepat".

Memperhatikan pendapat para ahli diatas, bahwa konsep efektivitas merupakan suatu konsep yang bersifat multidimensional, artinya dalam mendefinisikan efektivitas berbeda-beda sesuai dengan dasar ilmu yang dimiliki walaupun tujuan akhir dari efektivitas adalah pencapaian tujuan. Dalam setiap organisasi efektivitas merupakan unsur pokok untuk mencapai tujuan atau sasaran yang telah ditentukan di dalam setiap organisasi, kegiatan atau program. Disebut efektif apabila tercapai tujuan atau sasaran seperti yang telah ditentukan sebelumnya. Hal ini sesuai dengan pendapat Handayaningrat (2006:16) mengatakan bahwa "efektivitas adalah pengukuran dalam arti tercapainya tujuan yang ditentukan sebelumnya".

Jadi, penulis menganalisis bahwa efektivitas merupakan suatu sasaran yang ingin dicapai dengan memanfaatkan sejumlah sumber daya, sarana dan prasarana dengan jumlah tertentu yang telah di tetapkan sebelumnya dengan tujuan untuk menghasilkan sejumlah pekerjaan tepat pada waktunya. Sedangkan Tannenbaum dalam Steers (2005:50), mengemukakan : "Efektivitas ditinjau dari sudut pencapaian tujuan, dimana keberhasilan suatu organisasi harus mempertimbangkan bukan saja sasaran organisasi tetapi juga mekanisme mempertahankan diri dalam mengejar sasaran. Dengan kata lain, penilaian efektivitas harus berkaitan dengan masalah sasaran maupun tujuan". Berdasarkan pengertian tersebut penulis menganalisis bahwa efektivitas tidak hanya berbicara tentang pencapaian tujuan namun bagaimana organisasi dapat mempertahankan diri dari berbagai ancaman dari luar 
dan dari dalam sehingga organisasi dapat berkelanjutan dalam menjalankan tugas, pokok dan fungsi. Selanjutnya Steers (2008:87) bahwa efektivitas adalah : "Jangkauan usaha suatu program sebagai suatu sistem dengan sumber daya dan sasarannya tanpa melumpuhkan cara dan sumber daya itu serta tanpa memberi tekanan yang tidak wajar terhadap pelaksanaannya".

Berdasarkan pengertian tersebut penulis menganalisis bahwa efektivitas mengukur sejauh mana program organisasi berjalan di lapangan selain itu dapat mengukur tentang kendala dalam pelaksanaan program tersebut.

Tingkat efektivitas juga dapat diukur dengan membandingkan antara rencana yang telah ditentukan dengan hasil nyata yang telah diwujudkan. Namun, jika usaha atau hasil pekerjaan dan tindakan yang telah dilakukan tidak tepat sehingga menyebabkan tujuan tidak tercapai atau sasaran yang diharapkan, maka hal itu dikatakan tidak efektif.

Adapun kriteria atau ukuran mengenai pencapaian tujuan efektif atau tidak, sebagaimana dikemukakan oleh Campbell (1989: 121), yaitu :

1. Keberhasilan program

Program adalah sekumpulan aktiviti yang saling berkaitan dan bantu membantu di antara satu dengan lain kepada pencapaian sesuatu tujuan program itu. Sesebuah organisasi itu mungkin mengandungi satu atau lebih program dan tujuan tiap-tiap program itu adalah tidak serupa tetapi ia saling menyumbang kepada satu tujuan sesebuah organisasi itu.

Maksudnya adalah program yang diluncurkan oleh pemerintah benar-benar akan berhasil dalam kurun waktu yang dapat di tentukan sehingga masyarakat dapat menikmati program tersebut.

2. Keberhasilan sasaran

Sasaran/goal adalah suatu keadaan atau kondisi yang ingin dicapai oleh suatu organisasi, bisa tujuan jangka pendek atau jangka panjang, bisa mencakup organisasi keseluruhan dan bisa mencakup bagian organisasi tertentu, sebagai alat ukur efesien dan efektivitas organisasi. Tentunya program pemerintah mempunyai sasaran yang jelas dan terukur, baik sasaran siapa yang akan menikmati program, dan sasaran tersebut dapat melanjutkan secara mandiri program yang sudah bergulir.

3. Kepuasan terhadap program

Program yang dibuat oleh pemerintah benar-benar harus memuaskan seluruh komponen masyarakat tanpa terkecuali. Hal ini dilakukan agar masyarkat dapat menikmati keberhasilan program yang sedang bergulir.

4. Tingkat input dan output

Pada tingkat input dan output dapat dilihat dari perbandingan antara masukan (input) dengan keluaran (output). Jika output lebih besar dari input maka dapat dikatakan efesien dan sebaliknya jika input lebih besar dari output maka dapat dikatakan tidak efesien.

5. Pencapaian tujuan menyeluruh

Keberhasilan dari suatu program meerupakan tujuan utama dari pencapaian rencana. Artinya tujuan yang diharapkan harus menjadi tujuan umum dan mencakup kepentingan masyarakat tanpa terkecuali. 


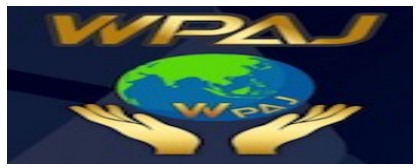

Volume 2 Issue 2, Desember 2020

http://ejournal.unsub.ac.id/index.php/publik

Berdasarkan efektivitas diatas, dapat dijalankan dengan kemampuan operasional dalam melaksanakan program-program kerja yang sesuai dengan tujuan yang telah di tetapkan sebelumnya, secara komprehensif, efektivitas dapat diartikan sebagai tingkat kemampuan suatu lembaga atau organisasi untuk dapat melaksanakan semua tugas-tugas pokoknya atau untuk mencapai sasaran yang telah ditentukan sebelumnya. Ukuran efektivitas merupakan upaya pencapaian tujuan melalui tahapan-tahapan yang telah di tentukan sebelumnya berdasarkan pencapaian tujuan, integrasi dan adaptasi. Pengukuran efektivitas program yang dikemukakan Annas (2017 : 76) yaitu:

1) Ketepatan waktu, program yang telah dirumuskan harus dilaksanakan dengan baik sesuai dengan waktu yang telah di tentukan. Hal ini dimaksud agar program-program tersebut menghasilkan output seperti yang diharapkan serta memberikan kepuasan kepada penerima program.

2) Sumber daya manusia yang mengelola program merupakan faktor penentu dalam keberhasilan program. Dalam hal ini pemilihan sumber daya manusia untuk melaksanakan program perlu dilakukan. Pemilihan sumber daya manusia ini berdasarkan kriteria yang sesuai dengan program yang dilaksanakan. Hal ini menekankan pada prinsip "the right man on the right job".

3) Mekanisme kerja, atau cara-cara yang ditempuh untuk melaksanakan program merupakan suatu aturan dan strategi yang telah di tetapkan untuk melaksanakan program. Apabila pegawai menerapkan mekanisme kerja yang baik, maka tujuan dari suatu program akan tercapai dengan baik pula.

4) Kerjasama dan komunikasi, perlu dilakukan dalam pelaksanaan program. Dalam konteks ini kerjasama dan komunikasi yang terjalin diantara para penyelenggara program, dan penyelenggara program dengan sasaran program.

5) Penyaluran dana yang benar, adalah suatu mekanisme kerja yang menyangkut pembiayaan program. Dana yang tersedia digunakan dengan efektif dan efesien.

6) Tidak adanya penyimpangan, hal ini lebih menekankan pada tidak adanya penyimpangan dalam menentukan sasaran program.

7) Monitoring dan evaluasi, merupakan kriteria terakhir dalam mengukur efektivitas. Dalam tahapan ini menjelaskan bahwa suatu program yang sedang dijalankan.

Menurut pendapat di atas dapat diketahui bahwa efektivitas harus mampu sesuai dengan waktu yang telah ditentukan, didalam ukurannya pun program yang dijalankan dapat tercapai.

Dari sejumlah definisi-definisi pengukuran efektivitas yang telah dikemukakan diatas, perlu peneliti tegaskan bahwa dalam rencana penelitian ini digunakan teori pengukuran sebagaimana yang dikemukakan oleh Annas (2017 : 76) yaitu: ketepatan waktu, sumber daya manusia, mekanisme kerja, kerjasama dan komunikasi, penyaluran dana yang benar, dan monitoring dan evaluasi. Karena teori ini sesuai apabila digunakan dala meneliti Efektivitas Program Desa Migran Produktif (Desmigratif) pada Dinas Tenaga Kerja dan Transmigrasi Kabupaten Subang.

\section{Pekerja Migran Indonesia}

Pekerja Migran Indonesia Menurut Pasal 1 Undang-Undang Nomor 18 Tahun 2017 tentang Perlindungan Pekerja Migran Indonesia, Pekerja Migran Indonesia adalah 
setiap warga negara Indonesia yang akan, sedang, atau melakukan pekerjaan dengan menerima upah di luar wilayah Republik Indonesia sedangkan menurut buku pedoman pengawasana perusahaan jasa Pekerja Migran Indonesia adalah warga negara Indonesia baik laki-laki maupun perempuan yang melakukan kegiatan di bidang perekonomian, sosial, keilmuan, kesenian, dan olahraga profesional serta mengikuti pelatihan kerja di luar negeri baik di darat, laut, maupun udara dalam jangka waktu tertentu berdasarkan perjanjian kerja yaitu suatu perjanjian antara pekerja dan pengusaha secara lisan dan atau tertulis baik untuk waktu tertantu maupun untuk waktu tidak tertentu yang memuat syarat-syarat kerja, hak dan kewajiban para pihak. Dengan adanya perjanjian kerja ini Pekerja Migran Indonesia akan lebih terlindungi apabila nantinya dikemudian hari pihak majikan atau menentukan sesuai perjanjian.Berdasarkan beberapa pengertian Pekerja Migran Indonesia tersebut, maka dapat dikemukakan bahwa Pekerja Migran Indonesia adalah setiap warga negara Indonesia yang memenuhi syarat untuk bekerja di luar negeri tempat dalam jangka waktu tertentu berdasarkan perjanjian kerja melalui prosedur penempatan Pekerja Migran Indonesia dengan menerima upah.

\section{Desa Migran Produktif}

Menurut Pedoman Program Desa Migran Produktif. Desa Migran Produktif (Desmigratif) adalah desa yang sebagian besar penduduknya bekerja di luar negeri, memahami sistem penempatan dan perlindungan tenaga kerja baik di dalam maupun di luar negeri, memiliki usaha produktif yang mandiri berbasis keluarga TKI, memiliki layanan bagi anak-anak TKI, melalui peran aktif pemerintah desa dalam melayani migrasi serta melibatkan pemangku kepentingan. Sesuai dengan Keputusan Menteri Ketenagakerjaan Nomor 59 Tahun 2017 tentang Penyelenggaraan Desa Migran Produktif, Program Desa Migran Produktif (Desmigratif) merupakan program untuk meningkatkan pelayanan dan perlindungan bagi Calon TKI, TKI purna beserta anggota keluarganya. Program Desmigratif diinisiasi oleh Kementerian Ketenagakerjaan dan memperoleh dukungan dari lintas sektor terkait, Program Desmigratif meliputi 4 (empat) kegiatan utama, yaitu 1) Membangun Pusat Layanan Migrasi, 2) Menumbuh kembangkan usaha-usaha produktif keluarga TKI dan TKI purna, 3) Pembentukan community parenting, dan 4) Menumbuh kembangkan koperasi produktif sebagai penguatan usaha produktif. Pelaksanaan ke 4 (Empat) program tersebut dilakukan secara terpadu, saling mendukung dan berkelanjutan. Untuk mendukung pelaksanaan program, Kementerian Ketenagakerjaan menempatkan 2 (dua) orang petugas lapangan dari warga setempat di setiap desa sasaran Program Desmigratif. Community parenting diartikan sebagai komunitas yang mendukung, peduli dan melakukan upaya untuk tumbuh kembang anak, pemeliharaan dan peningkatan derajat kesehatan bagi orang tua dan keluarganya.

Program Desmigratif mendorong dan memperkuat kabupaten/kota, Dalam pilar layanan migrasi,terdapat peran Kementerian Ketenagakerjaan serta Badan Nasional Penempatan dan Perlindungan TKI. Sedangkan pada pilar community parenting, Kementerian tenaga kerja bersinergi dengan Kementerian Kesehatan, Kementerian Pendidikan dan Kebudayaan, Kementerian Sosial, Badan Kependudukan dan Keluarga Berencana Nasional dan Kementerian Pemberdayaan Perempuan dan Perlindungan Anak. Berdasarkan Peraturan Menteri Ketenagakerjaanan Republik 
Indonesia Nomor 2 Tahun 2019 tentang Pemberdayaan Komunitas Pekerja Migran di Desa Migran Produktif.Landasan Hukum Peraturan Menteri Ketenagakerjaanan Republik Indonesia Nomor 2 Tahun 2019 tentang Pemberdayaan Komunitas Pekerja Migran Indonesia di Desmigratif bertujuan untuk :

a) Mewujudkan terbentuknya Komunitas Pekerja Migran Indonesia produktif;

b) Memperluas kesempatan kerja melalui penumbuhkembangan usaha produktif dan peningkatan keterampilan masyarakat Desa Migran;

c) Mewujudkan basis data Pekerja Migran Indonesia di tingkat desa;

d) Memberikan edukasi proses migrasi yang aman dan prosedural;

e) Meningkatkan peran aktif pemerintah pusat, pemerintah daerah, pemerintah desa, masyarakat, dan seluruh pemangku kepentingan; dan

f) Mewujudkan masyarakat Desa Migran yang produktif dan keluarga Pekerja Migran Indonesia yang sejahtera.

Program Desmigratif dilaksanakan dengan prinsip-prinsip sebagai berikut:

1) Kolaboratif : pelaksanaannya bekerjasama, bersinergi dan berintegrasi dengan berbagai kegiatan dan program yang terkait dari para pemangku kepentingan.

2) Partisipatif : masyarakat terlibat secara aktif dalam proses perencanaan, pelaksanaan, pemanfaatan dan pengawasan.

3) Berkelanjutan : setiap pengambilan keputusan dalam penyelenggaraan program Desmigratif harus mempertimbangkan peningkatan kesejahteraan Pekerja Migran Indonesia (PMI) dan keluarganya tidak hanya saat ini tetapi juga di masa depan.

\section{Metode Penelitian}

Metode penelitian yang digunakan dalam penelitian ini adalah deskriptif kualitatif, yakni desain yang memberikan kemudahan bagi peneliti untuk merekam, memantau dan mengikuti proses suatu kegiatan dalam hal ini Program Desa Migran Produktif (Desmigratif) pada Dinas Tenaga Kerja dan Transmigrasi Kabupaten Subang dalam suatu kurun waktu tertentu dan selanjutnya diinterpretasikan untuk jawab masalah penelitian.

Digunakannya metode penelitian deskriptif dengan pendekatan kualitatif, dimaksudkan untuk membuat deskripsi, gambar secara sistematis, faktual, dan akurat mengenai Efektifitas Program Desa Migran Produktif (Desmigratif) pada Dinas Tenaga Kerja dan Transmigrasi Kabupaten Subang, suatu kondisi pada masa sekarang serta hubungan antar fenomena yang diselidiki.

Penelitian kualitatif tidak dipersoalkan jumlah informan, tetapi bisa tergantung dari tepat atau tidaknya pemilihan informan kunci, dan kompleksitas dari keragaman fenomena sosial yang diteliti. Dengan demikian, penentuan informan dilakukan dengan teknik snowball sampling, yakni proses penentuan informan berdasarkan informan sebelumnya tanpa menentukan jumlah secara pasti dengan menggali informasi terkait topik penelitian yang ditentukan.

Adapun tujuan utama dari penelitian deskriptif kualitatif ini adalah mengembangkan pengertian, konep-konsep yang pada akhirnya memperoleh gambaran yang kemudian diarahkan pada deskriptif terhadap Efektivitas Program Desa Migran Produktif (Desmigratif) di Desa Pusakaratu pada Dinas Tenaga Kerja dan Transmigrasi Kabupaten Subang . 


\section{Hasil dan Pembahasan}

Kedudukan Dinas Tenaga Kerja dan Transmigrasi Kabupaten Subang

Berdasarkan Peraturan Daerah Kabupaten Subang Nomor 7 Tahun 2016 tentang Pembentukan dan Susunan Perangkat Daerah Kabupaten Subang dan Peraturan Bupati Subang Nomor 65 Tahun 2016 tentang Tugas Pokok dan Fungsi dan Tata Kerja Dinas Tenaga Kerja dan Transmigrasi adalah unsur pendukung tugas Pemeritah Daerah di bidang Ketenagakerjaan dan Transmigrasi yang dipimpin oleh seorang Kepala Dinas yang berada di bawah dan bertanggungjawab kepada Bupati melalui Sekretaris Daerah. Dinas Tenaga Kerja dan Transmigrasi Kabupaten Subang mempunyai tugas pokok Dinas Tenaga Kerja dan Transmigrasi adalah membantu Bupati dalam melaksanakan urusan pemerintahan di bidang Tenaga Kerja, Transmigrasi, Energi dan Sumber Daya Mineral yang menjadi kewenangan Daerah dan tugas pembantuan yang diberikan kepada Pemerintah Kabupaten.

Dinas mempunyai tugas pokok membantu Bupati dalam melaksanakan urusan pemerintahan di bidang Tenaga Kerja, Transmigrasi dan Energi Sumber Daya Mineral yang menjadi kewenangan daerah dan tugas pembantuan yang diberikan kepada Pemerintah Kabupaten Subang. Dinas mempunyai fungsi sebagai berikut :

1. Perumusan kebijakan teknis dibidang Tenaga Kerja Transmigrasi dan Energi Sumber Daya Mineral ;

2. Penyelenggaraan urusan pemerintahan dan pelayanan umum dibidang Tenaga Kerja, Transmigrasi dan Energi Sumber Daya Mineral sesuai dengan ketentuan yang ditetapan oleh Bupati ;

3. Pembinaan dan Pelaksanaan kegiatan dibidang Tenaga Kerja, Transmigrasi dan Energi Sumber Daya Mineral ;

4. Pengelolaan administrasi umum meliputi urusan perencanaan, evaluasi dan pelaporan, urusan umum dan kepegawaian serta urusan keunagan dan barang daerah

\section{Gambaran Umum Pelaksanaan Program Desa Migran Produktif (Desmigratif)}

Program Desa Migran Produktif (Desmigratif) adalah upaya terobosan Kementerian Ketenagakerjaan bekerja sama dengan berbagai lembaga untuk memberdayakan, meningkatkan pelayanan serta memberi perlindungan bagi CPMI/PMI di desa menjadi kantong-kantong Pekerja Migran, dengan menawarkan program-program unggulan yang dibutuhkan oleh CPMI/PMI dan keluarganya melalui pemanfaatan potensi lokal dengan tidak mengabaikan karakteristik daerah setempat. Tujuan utama program desa migran produktif adalah untuk melayani proses penempatan dan perlindungan calon tenaga kerja yang akan bekerja baik di dalam dan di luar negeri yang di mulai dari desa asal Pekerja Migran dan memberdayakan Pekerja Migran Purna beserta keluarganya serta mampu menekan tindak pidana perdagangan manusia ( human trafficking ) yang kerap melibatkan masyarakat desa sebagai korbannya.

a. Sasaran Program Desa Migran Produktif (Desmigratif)

1. Melayani, melindungi dan memberdayakan CTKI/TKI dan keluarganya sejak dari dan kembali ke daerah asal, dengan kriteria peserta sebagai berikut:

1. Calon TKI yaitu TKI yang akan berangkat ke luar negeri. 
2. Keluarga TKI yaitu suami/istri atau anak atau ayah/ibu dari TKI yang sedang bekerja di luar negeri.

3. TKI Purna yaitu TKI yang sudah tidak bekerja di luar negeri dan telah kembali ke daerah asal paling lama 3 (tiga) tahun setelah kepulangan.

2. Sasaran lokasi program Desmigratif yaitu di desa-desa asal TKI dengan jumlah TKI cukup banyak dan diutamakan desa dimana tingkat terjadinya permasalahan TKI cukup banyak, dengan kriteria sebagai berikut:

a. Desa dengan penduduk yang berusia produktif bekerja sebagai TKI

b. Desa dengan penduduk yang pernah mengalami permasalahan TKI

c. Desa dengan penduduk yang bekerja ke luar negeri tidak melalui mekanisme/non prosedural;

d. Desa asal TKI yang masuk dalam kategori desa tertinggal

b. Tujuan Program Desa Migran Produktif (Desmigratif) untuk :

1. mewujudkan terbentuknya Komunitas Pekerja Migran Indonesia produktif;

2. memperluas kesempatan kerja melalui penumbuhkembangan usaha produktif dan peningkatan keterampilan masyarakat Desa Migran;

3. mewujudkan basis data Pekerja Migran Indonesia di tingkat desa;

4. memberikan edukasi proses migrasi yang aman dan prosedural;

5. meningkatkan peran aktif pemerintah pusat, pemerintah daerah, pemerintah desa, masyarakat, dan seluruh pemangku kepentingan; dan

6. mewujudkan masyarakat Desa Migran yang produktif dan keluarga Pekerja Migran Indonesia yang sejahtera.

c. Kegiatan Program Desmigratif

Kegiatan Program Desa Migran Produktif (Desmigratif) meliputi :

1. Layanan Migrasi

Layanan Migrasi berfungsi untuk memberikan pelayanan informasi pasar kerja, bimbingan kerja, informasi mengenai bekerja ke luar negeri dan layanan dokumen bagi calon dan membantu menyelesaikan permasalahan TKI.

Layanan Migrasi meliputi :

a. IPK (Informasi Pasar Kerja) Online

b. Konseling Kerja

c. Pendataan / Pendaftaran Awal

Efektivitas Program Desa Migran Produktif (Desmigratif) pada Dinas Tenaga Kerja dan Transmigrasi Kabupaten Subang.

Berdasarkan hasil penelitian yang telah dilakukan di Kantor Dinas Tenaga Kerja dan Transmigrasi Jl. Mayjen Sutoyo Siswomiharjo No. 48, Karanganyar Kec. Subang Kabupaten Subang dan Lingkungan Desa Pusakaratu Kecamatan Pusakanagara Kabupaten Subang Efektivitas Program Desa Migran Produktif (Desmigratif) pada Dinas Tenaga Kerja dan Transmigrasi Kabupaten Subang dapat dilihat dari teori pengukuran efektivitas program yang dikembangkan oleh Answar Annas, sebagai berikut:

\section{Ketepatan Waktu}




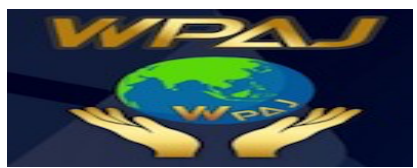

Volume 2 Issue 2, Desember 2020

http://ejournal.unsub.ac.id/index.php/publik

Ketepatan waktu dalam pelaksanaan program harus dilaksanakan dengan baik sesuai dengan waktu yang telah di tentukan. Pemerintah harus bisa menjalankan Program Desa Migran Produktif sesuai jadwal yang ada dengan proses yang tidak berbelit-belit dan sesuai prosedur yang ditetapkan, sehingga masyarakat mengetahui alur Layanan Terpadu Satu Atap serta Program-program Desa Migran Produktif lainnya. Menurut Kasi Perluasan Kesempatan Kerja pada Dinas Tenaga Kerja dan Transmigrasi, mengatakan sebagai berikut: " Pelaksanaan Program Desa Migran Produktif (Desmigratif) berjalan sesuai dengan jadwal yang telah ditetapkan oleh kementerian tenaga kerja. Dari Jadwal keberangkatan PMI, pelatihan pembekalan wirausaha, sampai program bantuan sarana usaha sehingga kami tidak merasakan kesulitan menjalankan Program Desa Migran Produktif ini. " Pendamping Kewirausahan Kementerian Tenaga Kerja mengatakan: " Pelaksanaan Program Desa Migran Produktif (Desmigratif) berjalan sesuai dengan jadwal yang telah ditetapkan oleh kementerian tenaga kerja melalui dinas tenaga kerja kabupaten subang dengan melakukan pendampingan yang ditunjuk langsung oleh kementerian program ini, dengan berbagai kegiatan diantaranya pelatihan pembekalan wirausaha, pendampingan selama program berlangsung dan pemberian bantuan sarana usaha bagi kelompok sesuai dengan apa yang menjadi usulan mereka dan potensi yang ada dilapangan Tetapi dikarenakan ini adalah Program yang dibiayai oleh APBN sehingga kadang waktunya sering mundur dengan alasan anggaran yang belum turun sehingga kami menunggu anggaran itu turun baru bisa mensosialisasikan Program tersebut. Kurangnya sosialisasi dari petugas karena waktunya yang sedikit disebabkan jadwalnya sudah diatur oleh pemerintah dan kita tinggal mengikutinya " Dalam pelaksanaannya masih mengalami berbagai hambatan. Pendapat yang sama juga dikemukakan oleh masyarakat sebagai berikut : "Banyak masyarakat yang kurang mengetahui informasi tentang Program Desa Migran Produktif (Desmigratif), disebabkan oleh kurangnya sosialisasi dari dinas, jadi hanya sebagian masyarakat yang mengetahui program ini. Petugas yang sedikit ditambah sosialisasi yang kurang kepada masyarakat menjadi salah satu penghambat masyarakat untuk mengetahui manfaat dari program Desa Migran Produktif padahal ini adalah program dari kementerian yang banyak bermanfaat bagi masyarakat. " Untuk mendapatkan hasil yang baik diperlukan ketepatan waktu, karena ketepatan waktu pelaksanaan suatu program dapat mempengaruhi hasil efektivitas suatu program. Dari hasil wawancara diatas dijelaskan bahwa Program Desa Migran Produktif (Desmigratif) belum populer dimasyarakat, dimana masih banyak masyarakat yang tidak mengetahui program ini.

Berdasarkan hasil beberapa wawancara diatas dapat ditarik kesimpulan, bahwa Ketepatan Waktu dalam Efektivitas Program Desa Migran Produktif (Desmigratif) pada Dinas Tenaga Kerja dan Transmigrasi Kabupaten Subang dinilai belum berjalan dengan optimal. Hal tersebut dinilai demikian berdasarkan sudut pandang peneliti dan hasil wawancara, dimana banyak faktor yang mempengaruhi sehingga Ketepatan Waktu dalam Efektivitas Program Desa Migran Produktif (Desmigratif) tidak bisa berjalan sesuai harapan.

\section{Sumber Daya Manusia}




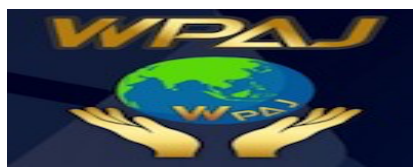

Volume 2 Issue 2, Desember 2020

http://ejournal.unsub.ac.id/index.php/publik

Sumber daya manusia sangat menentukan dalam keberhasilan suatu program. Pemilihan sumber daya manusia ini berdasarkan kriteria yang sesuai dengan program yang dilaksanakan. Sumber daya manusia yang handal adalah Sumber daya yang mengerti akan pelaksanaan program ini dengan ditunjang oleh pendidikan yang tinggi ditambah pengalaman bekerja. Untuk mendukung pelaksanaan program, Kementerian Ketenagakerjaan menempatkan 2 (dua) orang petugas lapangan dari warga setempat di setiap desa sasaran Program Desmigratif. Petugas yang bertugas di pusat informasi dan layanan migrasi merupakan staf Kantor Desa yang ditunjuk oleh Kepala Desa dan sudah mendapat pelatihan serta bimbingan dari Kementerian Ketenagakerjaan dan/atau instansi terkait.

Menurut Kasi Perluasan Kesempatan Kerja pada Dinas Tenaga Kerja dan Transmigrasi, mengatakan bahwa: "Pihak kami berusaha memberikan Pendampingan sebaik mungkin kepada masyarakat, kami siapkan petugas yang terbaik sehingga dapat mewujudkan Program Desa Migran Produktif (Desmigratif) diharapkan agar masyarakat mendapatkan pengetahuan yang bermanfaat sehingga mereka bisa mendapatkan kehidupan yang lebih layak setelah mengikuti Program Desa Migran Produktif (Desmigratif) ini. "

Berdasarkan hasil beberapa wawancara diatas dapat ditarik kesimpulan, bahwa Sumber Daya Masyarakat dalam Efektivitas Program Desa Migran Produktif (Desmigratif) pada Dinas Tenaga Kerja dan Transmigrasi Kabupaten Subang dinilai belum berjalan dengan optimal. Hal tersebut dinilai demikian berdasarkan sudut pandang peneliti dan hasil wawancara, dimana banyak faktor yang mempengaruhi sehingga Sumber Daya Manusia dalam Efektivitas Program Desa Migran Produktif (Desmigratif) tidak bisa berjalan sesuai harapan.

\section{Mekanisme Kerja}

Mekanisme kerja, yaitu cara-cara yang ditempuh untuk melaksanakan program merupakan suatu aturan dan strategi yang telah di tetapkan untuk melaksanakan program. Apabila menerapkan mekanisme kerja yang baik, maka tujuan dari suatu program akan tercapai dengan baik pula.

Selanjutnya peneliti mewawancarai Pendamping Desmigratif Desa, sebagai berikut : "Pelaksanaan program Desmigratif mengacu pada Rencana Aksi yang disusun secara sinergi sebagai berikut :

a. Memberikan Informasi dan Layanan Migrasi

Melalui pusat informasi dan layanan migrasi, warga desa yang ingin bekerja ke dalam dan luar negeri mendapatkan pelayanan informasi pasar kerja, bimbingan kerja, informasi mengenaiketenagakerjaan dan layanan dokumen bagi calon PMI seperti KTP, KK, surat keterangan atau dokumen lainnya sebagai dokumen awal yang dilaksanakan di balai desa melalui peran aktif dari pemerintah desa dalam pembuatan paspor, selain itu membantu menyelesaikan permasalahan PMI, dengan cara melapor dan mendaftarkan diri serta berkonsultasi dengan petugas pada pusat layanan layanan migrasi.

b. Menumbuhkembangkan Usaha Produktif.

Pemberdayaan masyarakat ditujukan untuk menumbuhkan dan mengembangkan usaha-usaha produktif PMI Purna dan Keluarganya di Desmigratif berbasis One Village One Product (OVOP), meliputi kegiatan pelatihan 
kewirausahaan/peningkatan keterampilan, pembinaan desa produktif, pendampingan, membantu mendapatkan akses permodalan,bantuan sarana usaha, bantuan pengemasan serta pemasaran produk.

c. Memfasilitasi Pembentukan Komunitas Pengasuhan Tumbuh Kembang Anak (Community Parenting) adalah wadah masyarakat dalam membentuk komunitas untuk memberikan bimbingan kepada keluarga PMI dalam hal mendidik, mengasuh dan membimbing anak dengan baik dan benar. Kegiatan ini dilakukan di "Rumah Belajar Desmigratif", dengan kegiatan antara lain: arena bermain anak, belajar anak, konseling tentang pembinaan keluarga dan anak PMI, taman baca (perpustakaan), pelatihan bahasa, pelatihan wirausaha dan pengelolaan keuangan yang baik dan lain-lain..

d. Memfasilitasi Pembentukan dan Pengembangan Koperasi/Lembaga Keuangan Kegiatan ini bertujuan untuk mendukung dan mengembangkan usaha- usaha yang dikelola oleh PMI dan keluarganya serta dapat memfasilitasi pengiriman uang dari luar negeri/remitance yang bekerjasama dengan lembaga perbankan. "

Dalam hasil wawancara diatas dijelaskan bahwa pihak Dinas Tenaga Kerja dan Transmigrasi dan Petugas Pendamping Desmigratif Desa dalam menjalankan tugasnya sudah memberikan pelayanan yang terbaik terhadap masyarakat, hal tersebut dilakukan berdasarkan prosedur yang telah ditetapkan oleh kementerian. Mereka pun bertanggungjawab untuk mencapai target dan tujuan program tersebut. Namun jawaban yang berbeda dikemukakan oleh masyarakat, masyarakat disini adalah Purna PMI, mengemukakan : " Pertugas memberikan Pelatihan Wirausaha budidaya ikan lele dan pelatihan pembuatan abon lele. Kami pun diberikan alat-alat untuk menunjang pelatihan tersebut. Tetapi kami ada kendala yaitu hasil pelatihan pembuatan abon lele tidak bisa diperjualbelikan secara luas karena terganjal pemasaran. Mereka pun tidak menjelaskan cara pembuatan sertifikasi dari BPOM, sertifikasi halal dari MUI, sertifikasi Dinkes P-IRT, dan sertifikasi Kemenkes RI. Masalah pemasaran pun mereka tidak memberikan arahan kemana kita harus menjual hasil produksi ini. Karena jika hanya dijual disekitar rumah tidak akan laku dan tidak bisa berkembang. Untuk Pembentukan Komunitas Pengasuhan Tumbuh Kembang Anak dilaksanakannya tidak di Rumah Belajar Desmigratif tetapi di masjid tempat anak-anak mengaji karena di rumah belajar itu kurang perlengkapannya dan tidak ada kadernya sehingga anak-anak tidak suka berada disana. "

Dalam hasil wawancara diatas dijelaskan bahwa selama ini masyarakat belum merasakan hasil dari pelatihan yang diberikan oleh petugas, mereka belum memiliki sertifikat-sertifikat yang dibutuhkan untuk menjual produk hasil pelatihan Abon Lele ke toko swalayan atau ke luar kota dan kurang efisiensinya pembangunan Rumah Belajar Desmigratif bagi anak-anak dan tidak adanya pembinaan bagi anak-anak yang orang tua menjadi PMI. Berdasarkan hasil wawancara diatas, dapat ditarik kesimpulan bahwa Mekanisme Kerja dalam Efektivitas Program Desa Migran Produktif (Desmigratif) pada Dinas Tenaga Kerja dan Transmigrasi Kabupaten Subang dinilai belum berjalan dengan optimal. Hal tersebut terjadi karena hasil pelatihan yang diberikan petugas dalam pendampingan purna PMI belum memberikan dampak yang baik bagi mereka.

\section{Kerjasama dan Komunikasi}




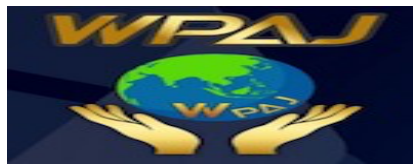

Volume 2 Issue 2, Desember 2020

http:/ / ejournal.unsub.ac.id/index.php/publik

Kerjasama dan komunikasi, perlu dilakukan dalam pelaksanaan program. Dalam konteks ini kerjasama dan komunikasi yang terjalin diantara para penyelenggara program, dan penyelenggara program dengan sasaran program. Menurut Kasi Perluasan Kesempatan Kerja pada Dinas Tenaga Kerja dan Transmigrasi, mengatakan bahwa: " Program Desa Migran Produktif (Desmigratif) diperlukan koordinasi antara pemerintah pusat, pemerintah daerah dan desa migran produktif, sehingga program ini bisa berjalan dengan baik dan lancar. Karena dengan kerjasama dan komunikasi yang baik maka dapat tercapai tujuan Program Desa Migran Produktif (Desmigratif) yang diharapkan. Kerjasama dan komunikasi diperlukan dari mulai perencanaan sampai dengan evaluasi. Tanpa adanya Kerjasama dan komunikasi dengan dinasdinas terkait maka program ini tidak akan berjalan dengan lancar dan berkesinambungan. Contoh dalam proses pemberangkatan Kita bekerjasama dengan pemerintah desa, Disdukcapil, Dinas Kesehatan, Kepolisian, dan BPJS Ketenagakerjaan, sehingga PMI itu bisa berangkat secara legal ". Selanjutnya peneliti mewawancarai Pendamping Desmigratif Desa, sebagai berikut : "Kerjasama dan komunikasi adalah hal yang tidak bisa dipisahkan dalam Program Desa Migran Produktif (Desmigratif). Karena ke 2 (dua) hal tersebut, program ini akan berjalan dengan lancar. Kerjasama dan komunikasi yang dibangun oleh dinas terhadap masyarakat harus intens, baik dari sisi komunikasi maupun personal. Kerjasama dan komunikasi antara Dinas dengan pendamping dilaksanakan sewaktu-waktu. Tetapi jika ada masalah dilapangan mereka bisa di telepon. Begitu pula dengan pelatihan dan pembinaan untuk purna PMI kita selalu komunikasikan sehingga terlaksananya pelatihan, pembinaan dan bantuan sarana bagi mereka. " Dalam hasil wawancara diatas dijelaskan bahwa Dinas Tenaga Kerja dan Transmigrasi dalam mengadakan Kerjasama dan komunikasi sudah memberikan pelayanan yang baik terhadap masyarakat, hal tersebut dilakukan berdasarkan sesuai prosedur yang telah ditetapkan. Tetapi jawaban yang berbeda di kemukakan oleh masyarakat, masyarakat disini adalah Purna PMI, mengemukakan : " Pendamping datangnya tidak rutin tiap bulan datangnya, tapi kalau ada kegiatan dari dinas, mereka pasti datang. Seharusnya mereka sering mengadakan pertemuan dengan kami, sehingga kami bisa lebih dekat dan bisa menambah persaudaraan. Pas pelatihan kita dikasih ilmu, dikasih tahu variasi olahannya, dikasih alat-alat buat produksinya, tetapi begitu selesai kita tidak didampingi lagi. Terus hasil pelatihan pembuatan abon lele dijualnya kemana? Jadi terkesannya sia-sia ada pelatihan juga. Karena kami tidak diberikan solusi dalam penjualannya. Karena kalau dijualan diwarung-warung dekat sini tidak akan laku, kalau masuk supermarket tidak diterima sebab kita tidak memiliki ijin usaha, sertifikasi dari BPOM, sertifikasi halal dari MUI, sertifikasi Dinkes P-IRT, dan sertifikasi Kemenkes RI. Seharusnya dari Dinas Tenaga Kerja bekerja sama dengan Dinas terkait untuk memberikan akses kemudahan membuat pembuatan ijin usaha serta pembuatan sertifikat-sertifikat yang dibutuhkan, sehingga hasil pelatihan bisa dirasakan lebih bermanfaat lagi. Dalam segi pemasaran pun kita tidak tahu harus dijual kemana? Seharusnya dinas bisa menfasilitasi hasil produk pelatihan dijual kemana. Ya kalo bisa masuk ke toko bumdes bahkan kalo bisa sampai masuk ke toko swalayan. Karena Pembentukan Koperasi untuk Purna PMI belum berjalan dengan semestinya " 
Berdasarkan hasil wawancara diatas, dapat ditarik kesimpulan bahwa Kerjasama dan komunikasi dalam Efektivitas Program Desa Migran Produktif (Desmigratif) pada Dinas Tenaga Kerja dan Transmigrasi Kabupaten Subang dinilai belum berjalan dengan optimal. Hal tersebut terjadi karena hasil pelatihan belum memberikan dampak yang baik bagi mereka.

\section{Penyaluran Dana yang Benar}

Penyaluran dana yang benar adalah suatu mekanisme kerja yang menyangkut pembiayaan program. Dana yang tersedia digunakan dengan efektif dan efesien. Menurut Kasi Perluasan Kesempatan Kerja pada Dinas Tenaga Kerja dan Transmigrasi, mengatakan bahwa : "Setelah mengikuti pelatihan para peserta dibentuk dalam satu kelompok. Kelompok tersebut akan menerima bantuan sarana usaha, nanti akan dibelanjakan sesuai kebutuhan mereka. Anggaran tersebut sudah mencukupi untuk Program Desa Migran Produktif (Desmigratif) dan kita langsung salurkan kepada kelompok masyarakat Purna PMI. "Selanjutnya menurut Pendamping Desmigratif Desa, sebagai berikut: “Anggaran yang selama ini diterima dirasa belum mencukupi dikarenakan masih banyak warga masyarakat yang belum merasakan program Desa Migran Produktif (Desmigratif). Program Desa Migran Produktif (Desmigratif) memberikan Sumbangan kepada Peserta pelatihan, barangbarang yg diberikan disesuaikan dengan kebutuhan. Barang yang akan diberikan kepada kelompok budidaya ikan lele yaitu Terpal, bioplok, Pompa Sirkulasi, indukan Ikan Lele terus pakan Ikan Lele. Sedangkan barang-barang yang diberikan kepada kelompok pelatihan pembuatan abon lele seperti tabung gas, perlengkapan memasak, spiner serta blender." Hal ini dibenarkan oleh masyarakat yaitu sebagai berikut : " Harusnya masyarakat bisa lebih banyak lagi yang merasakan Program Desa Migran Produktif (Desmigratif), sehingga masyarakat purna PMI bisa lebih berkembang. Fasilitas dari pemerintah yang berupa pelatihan dan Sumbangan peralatan untuk masyarakat dirasa sudah mencukupi, walaupun bantuannya hanya sedikit tapi berarti buat kita. Dimohon dilengkapi lagi perlengkapan di Rumah Belajar Desmigratif sehingga anak-anak bisa memanfaatkan keberadaan Rumah Belajar Desmigratif ". Dalam hasil wawancara diatas dijelaskan bahwa selama ini purna PMI masih kurang merasakan manfaat dari Program Desa Migran Produktif (Desmigratif). Dikarenakan penyaluran dana yang belum merata dan masih terbatas, sehingga tidak semua purna PMI mendapatkan pelatihan dari Dinas Tenaga Kerja dan Transmigrasi Kabupaten Subang. Berdasarkan hasil wawancara diatas, dapat ditarik kesimpulan bahwa Penyaluran Dana dalam Efektivitas Program Desa Migran Produktif (Desmigratif) pada Dinas Tenaga Kerja dan Transmigrasi Kabupaten Subang dinilai belum berjalan dengan optimal. Hal tersebut terjadi karena masih banyak purna PMI yang belum merasakan program tersebut .

\section{Tidak Adanya Penyimpangan}

Tidak adanya penyimpangan, hal ini lebih menekankan pada tidak adanya penyimpangan dalam menentukan sasaran program sehingga program tersebut bisa tepat sasaran dan berjalan dengan semestinya. Menurut Kasi Perluasan Kesempatan Kerja pada Dinas Tenaga Kerja dan Transmigrasi, mengatakan bahwa : " Dalam program Desa Migran Produktif (Desmigratif) tidak ada penyimpangan dikarenakan 


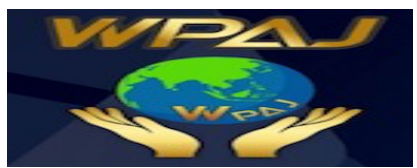

Volume 2 Issue 2, Desember 2020

http://ejournal.unsub.ac.id/index.php/publik

kita mengerjakan sesuai dengan arahan dari pusat, kita mengikutinya Standar Operasional Prosedur dari Pusat, mulai rekrutmen peserta pengumpulan persyaratan hingga pelaksanaan kegiatan, sehingga kegiatan program Desa Migran Produktif (Desmigratif) bisa berjalan dengan lancar. ". Selanjutnya menurut Pendamping Desmigratif Desa, sebagai berikut: " Program Desa Migran Produktif (Desmigratif) adalah program dari kementerian tenaga kerja yang bertujuan untuk menciptakan kesempatan kerja di sector informal dan mengembangkan kader-kader wirausaha baru yang mandiri dan produktif dengan mengoptimalkan sumber daya alam di daerah. Kami lakukan semua sesuai dengan Standar Operasional Prosedur yang diberikan oleh kementerian, sehingga kegiatan ini berjalan sesuai harapan." Dalam hasil wawancara diatas dijelaskan bahwa Dinas Tenaga Kerja dan Transmigrasi dalam mengadakan program sudah memberikan pelayanan yang baik terhadap masyarakat, hal tersebut dilakukan berdasarkan sesuai prosedur yang telah ditetapkan. Sesuai dengan yang di kemukakan oleh masyarakat yaitu : " Program ini sangat bagus untuk masyarakat karena bisa meningkatkan kemampuan masyarakat dalam melakukan kegiatan usaha dan mampu menciptakan lapangan kerja mandiri sehingga diharapkan dapat menurunnya tingkat permasalahan penempatan PMI ke luar negeri dan berkurangnya kasus-kasus trafficking". Berdasarkan hasil wawancara diatas, dapat ditarik kesimpulan bahwa Tidak Ada Penyimpangan dalam Efektivitas Program Desa Migran Produktif (Desmigratif) pada Dinas Tenaga Kerja dan Transmigrasi Kabupaten Subang sehingga bisa dinilai berjalan dengan optimal.

\section{Monitoring dan Evaluasi}

Monitoring dan evaluasi, merupakan kriteria terakhir dalam mengukur efektivitas. Dalam tahapan ini menjelaskan bahwa suatu program yang sedang dijalankan. Menurut Kasi Perluasan Kesempatan Kerja pada Dinas Tenaga Kerja dan Transmigrasi, mengatakan bahwa: " Monitoring dan evaluasi harus dilakukan karena kita harus mencapai target Indikator keberhasilan yang diharapkan dalam program Desmigratif yaitu:

Indikator Output

a) Tersedianya sarana informasi dan berfungsinya layanan tata kelola TKI di balai desa.

b) Terlaksananya pemberdayaan masyarakat berupa pelatihan kewirausahaan/skill, pendampingan, bantuan sarana usaha dan bantuan peralatan pengemasan serta pemasaran baik online maupun offline.

c) Tersedianya sarana pelatihan di lembaga pelatihan kerja swasta (LPKS) dan atau di lembaga yang bergerak di bidang pelatihan kerja yang ada di desa migran produktif.

d) Tersedianya sarana dan berfungsinya pusat aktifitas sosial masyarakat di Rumah Belajar Desmigratif, yang merupakan tempat untuk antara lain: bermain anak, belajar anak, konseling, taman baca, belajar bahasa asing, pelatihan wirausaha, dan lain-lain.

e) Terbentuk dan atau berkembangnya koperasi atau lembaga keuangan lain yang produktif dan berkelanjutan.

f) Terselenggaranya koordinasi, sinkronisasi, dan integrasi para pemangku kepentingan untuk pengembangan Desmigratif. 
g) Meningkatnya pemahaman masyarakat tentang mekanisme bekerja ke luar negeri secara prosedural.

h) Tumbuh dan berkembangnya usaha-usaha produktif.

i) Terlaksananya pendidikan dan pengasuhan terhadap anak-anak TKI secara baik dan benar.

Indikator Outcome

a) Menurunnya persentase TKI non prosedural.

b) Meningkatnya jumlah wirausaha produktif.

c) Meningkatnya kontrol sosial masyarakat tehadap tumbuh kembangnya anak anak.

d) Meningkatnya kesadaran orang tua tentang pentingnya pendidikan dan pola asuh anak.

e) Meningkatnya kesadaran masyarakat tentang kualitas hidup (PHBS- Pola hidup bersih dan sehat)

f) Meningkatnya kesadaran masyarakat terhadap pengelolaan keuangan.

g) Meningkatnya permodalan masyarakat.

h) Meningkatnya jumlah masyarakat yang memanfaatkan layanan koperasi dan atau lembaga keuangan lainnya.

i) Meningkatnya koordinasi, sinkronisasi dan integrasi para pemangku kepentingan untuk pengembangan Desmigratif.

j) Meningkatnya jumlah anak-anak TKI yang mendapatkan pendidikan.

k) Meningkatnya jumlah tenaga kerja yang terampil dan kompeten Indikator Benefit

a) Menurunnya tingkat permasalahan penempatan TKI ke luar negeri dan berkurangnya kasus-kasus trafficking in person.

b) Meningkatnya pendapatan dan daya beli masyarakat.

c) Meningkatnya ketahanan keluarga dan terpenuhinya hak-hak anak keluarga TKI.

d) Meningkatnya jumlah kesempatan kerja di desa.

Dalam hasil wawancara diatas dijelaskan bahwa Dinas Tenaga Kerja dan Transmigrasi dalam mengadakan program sudah memberikan pelayanan yang baik terhadap masyarakat, tetapi ada hal-hal yang menjadi kendala dilapangan hal tersebut juga dibenarkan oleh masyarakat yaitu : “ Tidak ada monitoring dari Dinas Tenaga Kerja dan Transmigrasi, mereka cuma datang pas pertama dan pas pelatihan saja, jadi selama ini yang kita temui cuma pendamping saja. Untuk kegiatan Comunity Parenting seharusnya Dinas Tenaga Kerja dan Transmigrasi bekerjasama dinas BP3P2KB dan TP.PKK untuk melakukan pembinaan dan perlindungan terhadap anak-anak, dilengkapi lagi perlengkapannya yang lengkap seperti mainan eduksi, buku-buku bacaan, serta didampingi oleh tutor yang pengalaman. Untuk Pembentukan dan Pengembangan Koperasi bisa bekerjasama dengan Dinas Koperasi, UMKM, Perdagangan dan Perindustrian. sehingga ada pembinaan dalam pembentukan koperasi dari DKUPP. Untuk program Usaha Produktif seharusnya berkerjasama dengan DKUPP dan pemerintah desa setempat dalam proses pengemasan dan pemasaran produk hasil pembuatan abon lele". Dalam hasil wawancara diatas dapat ditarik kesimpulan, bahwa Monitoring dan evaluasi dalam Program Desa Migran Produktif (Desmigratif) dinilai belum berjalan dengan optimal, disebabkan oleh masih banyak PMI yang belum merasakan perubahan hidup yang 
lebih baik setelah mereka menjadi purna PMI dan mengikuti program Desa Migran Produktif (Desmigratif). Berdasarkan hasil wawancara diatas dijelaskan bahwa Monitoring dan evaluasi dalam Program Desa Migran Produktif (Desmigratif) masih belum memberikan dampak yang optimal bagi masyarakat. Dari beberapa hasil wawancara diatas tentang Ketepatan Waktu, Sumber Daya Manusia, Mekanisme Kerja, Kerjasama dan komunikasi, Penyaluran dana yang benar, Tidak adanya penyimpangan dan Monitoring dan Evaluasi dalam Program Desa Migran Produktif (Desmigratif) di nilai belum optimal. Hal tersebut dinilai berdasarkan sudut pandang peneliti dan hasil wawancara dari narasumber dimana temuan dilapangan mengenai dampak dari Efektivitas Program belum sesuai dengan teori yang dikemukakan oleh Answar Annas.

\section{Kesimpulan}

Berdasarkan hasil penelitian dan pembahasan terhadap permasalahan yang telah dikemukakan sebelumnya, dapat ditarik kesimpulan sebagai temuan penelitian yaitu bahwa Efektivitas Program Desa Migran Produktif (Desmigratif) pada Dinas Tenaga Kerja dan Transmigrasi Kabupaten Subang diukur berdasarkan teori pengukuran efektivitas program yang dikembangkan oleh Answar Annas, sebagai berikut:

1. Ketepatan Waktu, berdasarkan sudut pandang peneliti dan hasil wawancara dengan Kasi Perluasan Kesempatan Kerja pada Dinas Tenaga Kerja dan Transmigrasi, Pendamping serta masyarakat Purna PMI, dimana Program Desa Migran Produktif (Desmigratif) belum populer dimasyarakat karena masih banyak masyarakat yang tidak mengetahui program ini. Hal ini disebabkan karena Program ini dibiayai oleh APBN sehingga waktunya sering mundur dengan alasan anggaran yang belum turun sehingga Ketepatan Waktu dalam Efektivitas Program Desa Migran Produktif (Desmigratif) pada Dinas Tenaga Kerja dan Transmigrasi Kabupaten Subang dinilai belum berjalan dengan optimal

2. Sumber Daya Manusia, Program Desa Migran Produktif (Desmigratif) belum dipahami masyarakat, disebabkan oleh Kurangnya Sosialisasi dari petugas dikarenakan petugas yang kurang menguasai program tersebut di tambah pula dengan beberapa faktor yang mempengaruhi masyarakat seperti faktor usia, faktor pendidikan dan faktor kebiasaan masyarakat sehingga Sumber Daya Masyarakat dalam Efektivitas Program Desa Migran Produktif (Desmigratif) pada Dinas Tenaga Kerja dan Transmigrasi Kabupaten Subang dinilai belum berjalan dengan optimal

3. Mekanisme Kerja, masyarakat belum merasakan hasil dari pelatihan yang diberikan oleh petugas, karena masyarakat belum bisa mengemas produk dengan baik dan belum memiliki sertifikat-sertifikat yang dibutuhkan untuk menjual produk hasil pelatihan Abon Lele dan Kurang efisiensinya pembangunan Rumah Belajar Desmigratif bagi anak-anak sehingga Mekanisme Kerja dalam Efektivitas Program Desa Migran Produktif (Desmigratif) pada Dinas Tenaga Kerja dan Transmigrasi Kabupaten Subang dinilai belum berjalan dengan optimal.

4. Kerjasama Dan Komunikasi, masyarakat belum merasakan manfaat dari hasil pelatihan yang diselenggarakan, hal itu terjadi karena Belum terjalinnya komunikasi yang baik antar dinas terkait sehingga hasil akhir program tersebut belum bisa dirasakan oleh purna PMI secara optimal sehingga Kerjasama dan 
komunikasi dalam Efektivitas Program Desa Migran Produktif (Desmigratif) pada Dinas Tenaga Kerja dan Transmigrasi Kabupaten Subang dinilai belum berjalan dengan optimal.

5. Penyaluran Dana Yang Benar, tidak semua purna PMI bisa merasakan manfaat dari Program Desa Migran Produktif (Desmigratif). Dikarenakan penyaluran dana yang belum merata dan masih terbatas, sehingga tidak semua purna PMI mendapatkan pelatihan sehingga Penyaluran Dana dalam Efektivitas Program Desa Migran Produktif (Desmigratif) pada Dinas Tenaga Kerja dan Transmigrasi Kabupaten Subang dinilai belum berjalan dengan optimal.

6. Tidak Ada Penyimpangan, dalam program Desa Migran Produktif, karena semua berjalan sesuai program pemerintah sehingga Tidak Ada Penyimpangan dalam Efektivitas Program Desa Migran Produktif (Desmigratif) pada Dinas Tenaga Kerja dan Transmigrasi Kabupaten Subang sehingga bisa dinilai berjalan dengan optimal.

7. Monitoring Dan Evaluasi, masih banyak PMI yang belum merasakan perubahan hidup yang lebih baik setelah mereka menjadi purna PMI dan mengikuti program Desa Migran Produktif (Desmigratif) sehingga monitoring dan evaluasi dalam Program Desa Migran Produktif (Desmigratif) dinilai belum berjalan dengan optimal

\section{Referensi}

Annas, Aswar. 2017 Interaksi Pengambilan Keputusan dan Evaluasi Kebijakan. Jakarta : Celebes Media Perkasa

BPS, 2018, Data Kabupaten Subang, 2018

BPS, 2018, Data Kecamatan Pusakanagara, 2018

Campbell, JP 1989, Teori Efektivitas, dalam Richard M: Efektivitas Organisasi 2005 Bandung: Erlangga

Danim Sudarwan 2012. Motivasi, Kepemimpinan dan Efektivitas Kelompok. PT. RINEKA CIPTA, Jakarta 13150

Departemen Tenaga Kerja dan Transmigrasi Republik Indonesia. 2006. Laporan Tahunan Kondisi Tenaga Kerja Indonesia. Jakarta.

Fathoni, Abdurahmant. 2010. Organisasi dan Manajement Sumber Daya Manusia. PT. RINEKA CIPTA.

Guba, Egon G. dan Yvonna S. Lincoln. (1981). Effective Evaluation. San Fransico: Jossey-Bass Publisher.

Hadi, Sutrisno. 2007. Metodologi Research. Yogyakarta: UGM

Handayaningrat, suewarno, 1995. Pengantar Studi Ilmu Administrasi dan Management, Jakarta: PT. Gunung Agung

Ida Bagus Mantra, 2003. Demografi Umum Edisi Kedua, Pustaka Pelajar. Yogyakarta 


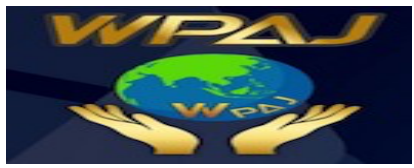

Volume 2 Issue 2, Desember 2020

http:// ejournal.unsub.ac.id/index.php/publik

Lubis, Hari. S.B. dan Martani Husaini. 1987. Teori Organisasi (Suatu Pendekatan Makro) Jakarta: Pusat Antar Universi

Makmur, S. (2008) "Pemberdayaan Sumber Daya Manusia dan Efektivitas Organisasi", Jakarta: Penerbit Rajawali Pers.

Mardikanto Totok dan Soebiato Poerwoko (2013). Pemberdayaan Masyarakat dalam Perspektif Kebijakan Publik. Alfabeta, Bandung.

Moleong Lexy J. M.A. 2010. Metodelogi Penelitian Kualitatif. PT Remaja Rosdakarya. Bandung.

Peraturan Menteri Ketenagakerjaanan Republik Indonesia Nomor 2 Tahun 2019 Tentang Pemberdayaan Komunitas Pekerja Migran di Desa Migran Produktif.

Rozy Munir. 2000. Migrasi Dalam Dasar-Dasar Demografi Disunting oleh Lembaga Demografi Fakultas Ekonomi Universitas Indonesia. Jakarta : Lembaga Penerbit Fakultas Ekonomi Universitas Indonesia.

Sadarmayanti, M.Pd,. APU. (2009), Sumber Daya Manusia dan Produktivitas Kerja. Bandung: Penerbit Mandar Maju.

Steers, Richard M. 2005. Efektivitas Organisasi. Terjemahan Magdalena Jamin. Erlangga. Jakarta.

Siagian, Sondang P, 2001 Manajemen Sumber Daya Manusia, Jakarta: PT. Bumi Aksara.

Siagian, Sondang P. 2005. Fungsi-fungsi Manajemen. Jakarta : Bumi Aksara

Siagian, Sondang P. 2008. Admnistrasi Pembangunan, Konsep, Dimensi dan Strateginya, Jakarta : Bumi Aksara

Siagian, Sondang P. 2011. Filsafat Administrasi Edisi Revisi. Jakarta : PT. Bumi Aksara

Sugiyono, 2007. Statistika Untuk Penelitian, Bandung: Alfabet.

Sugiyono, 2009. Memahami Penelitian Kualitatif. Bandung: Alfabet

Sumaryadi. 2005. Perencanaan Pembangunan Daerah Otonom dan Pemberdayaan Masyarakat. Jakarta: Citra

Supriyono. 2000. Efektivitas Kerja. Jakarta : Pascasarjana UNJ

Streets, Richard M. 2005. Efektifitas Organisasi. Erlangga: Jakarta.

Tangkilisan, Hessel Nogi S. 2005. Manajemen Publik. Jakarta: Gramedia Widia Sarana Indonesia

Tjokroamidjojo, Bintaro, 1994, Perencanaan Pembanguna, CV. Haji Masagung, Jakarta

Undang-Undang Nomor 18 Tahun 2017 Tentang Perlindungan Pekerja Migran Indonesia 